\title{
THE AWARENESS TOWARDS QUALITY OF SERVICE FROM HOMESTAY PROVIDERS IN PREMIUM TOURISM DESTINATION
}

\author{
Gregorius Antariksa Berybe, Elisabeth Oktaviani Hanggu dan Maria Beatrix \\ Rahinart Wellalangi \\ Politeknik eLBajo Commodus, Nusa Tenggara Timur \\ Email: gregberybe@poltekelbajo.ac.id, elisabetoktaviani@poltekelbajo.ac.id dan \\ maria.wellalangi@poltekelbajo.ac.id
}

\begin{abstract}
This research aims to know the understanding of homestay providers about the quality of service. The research design of this study is descriptive quantitative where data collected from the questionnaires that given to the homestay providers at Liang Ndara Village, Labuan Bajo, with factors of analysis are: 1) Tourism Awareness, 2) Sanitation and Hygiene, 3) Psychology of Service, 4) Guest Service and English for Communication. The result of this study shows that $84,9 \%$ of respondents are not aware of the importance of sanitation and hygiene. English as a communication shows about $78,2 \%$ of respondents are not using English as daily communication with the foreign guest. This lack of interaction because of the effect of the psychology of service $(8 \%)$ of respondents are less confident having interaction. While factors shown by the respondents are highly aware such as tourism awareness (100\%) and $86,9 \%$ respondents have shown their awareness of service. Providing quality of service is required commitment from respondents to aware of those factors.
\end{abstract}

Keywords: homestay; quality service; ASEAN homestay standard

\section{Introduction}

The establishment of Labuan Bajo as a premium tourist destination from the Indonesian Government has increased the visitor rate either local or international. According to the Tourism Office of West Manggarai Regency, in 2018, the number of tourists is 163.054 and it reaches 187.098 in 2019. This increased number of tourist visits gives an impact on the accommodation sector. The number of accommodation facilities in West Manggarai itself is 98 consisting of star rating hotels and nonstar rating in 2018 (manggaraibaratkab.go.id).

One of the tourist accommodations is a homestay. Often located in rural areas actively owned, managed, and operated by the communities where tourists reside and enjoy the local traditional activities and cultural performances (Acharya and Halpenny, 2013). Generally speaking, the location of the homestay is in the village area with the aiming for local community development. The existence of homestay in the village as an economic wheel for the locals with the efforts of daily activities from the local

$\begin{array}{ll}\text { How to cite: } & \begin{array}{l}\text { Berybe, R Gregorius Antariksa., et., al. (2021) The Awareness Towards Quality of Service From } \\ \text { Homestay Providers In Premium Tourism Destination. Syntax Literate: Jurnal Ilmiah Indonesia. 6(4). } \\ \text { http://dx.doi.org/10.36418/syntax-literate.v6i4.2526 }\end{array} \\ \text { E-ISSN: } & 2548-1398 \\ \text { Published by: } & \text { Ridwan Institute }\end{array}$


Gregorius Antariksa Berybe, Elisabeth Oktaviani Hanggu dan Maria Beatrix Rahinart Wellalangi

community. One of the tourism villages in West Manggarai Regency is Liang Ndara Village. In 2020, the number of homestays in Liang Ndara village alone is 25 (twentyfive). The presence of a quality homestay that matches to (ASEAN Homestay Standard, n.d.) becomes important to support the improvement of tourism in Liang Ndara.

Lanier and Berman in (Wedatama \& Mardiansjah, 2018) homestay is a condition where the tourist who comes to visit a destination place chooses to rent accommodation during the visit such as villager's own house in the community in which an empty room is provided to meet and interact with the visitor possible and that it adds the owner's house income up from the cost payment. Homestay itself makes an opportunity as a source of income as it was also explained by (Kontogeorgopoulos, Churyen, \& Duangsaeng, 2015) that homestay represents the process of commercializing a residential space for profitable purposes. Concerning management homestay, a local community in Liang Ndara is demanded to offer quality service. The standard of homestay management includes sanitation and hygiene of homestay and environmental around, guest service standard, self-confidence when meeting the guest, and supported by basic English competence for communication as a foundation to creating interaction between the homestay providers and the tourist.

The challenge faced by the destination management is how far the awareness of homestay providers regarding the factors that influence the quality service referring to the (ASEAN Homestay Standard, n.d.). The activity and the familiar atmosphere in a homestay make it possible for the guests to feel directly the way of life from the local community with the touch quality service. As (Kontogeorgopoulos et al., 2015) have stated that homestay in the tourism village enables the guests to see and feel a slight look at the daily life of the villagers which is different from conventional tourism.

The awareness of the homestay provider of his role as tourism agent in the village has an impact on guest service. The lack of awareness of his role may cause obstacles to the tourism development around. The previous research shows that the local's support beyond the tourism is very important for the success of the community's participation just because of the locals' level of understanding following the other stakeholders' also stated that Managed tourism can make a positive contribution to destinations, and thus it could receive support from the local communities (Aref \& Redzuan, 2009). It is important to have a prior evaluation of the level of the local community awareness and their knowledge about their perception of tourism development in their area. Not only to help to identify the imbalance in the understanding of the community about the concept but also to enlarge the program and policy that can be used as a guide for the community to be more apprehensive on the process for tourism development (Ismail, Hanafiah, Aminuddin, \& Mustafa, 2016). Basic competence of homestay management is fundamental concerning providing quality service.

The importance of service psychology is to know the attitude of the homestay provider relate to interaction and servicing guests. Performance (personal grooming) of the homestay provider reflects cleanliness, health, and it affects the feel of comfort on 
the side of the service user (guest) (Suhartoyo, 2019). The attitude when interacting with the guest will affect satisfaction for the customer. Service as an economic activity is consumed when produced and it gives an additional value of entertainment package, comfort, health, ease and need, and other customer's desires. The concept of widely more acceptable quality service is more comparatively and it concentrates on the difference between the expectation of the customer on the service work and actual experience in service work (Review, Osman, \& Sentosa, 2013).

Sanitation and hygiene are important elements in the hospitality industry. According to (Wahyunanto, 2018), sanitation is all efforts to prevent disease focusing on the human-environmental health effort. The focus of sanitation is a clean environment. While hygiene is the cleanliness as a process of how people keep and take care of self-health (Auliya \& Aprilia, 2016), where the focus is on personal hygiene (homestay provider).

As a part of the hospitality industry, homestay is run in the accommodation sector by providing guest facilities services such as room reservation, food and beverage services, souvenirs, or local activities. Services will help identify gaps in the community's understanding of the concept, but also to develop programs and policies that can guide people to better understand the process and importance of tourism development (Cárdenas, Byrd, \& Duffy, 2015).

The interaction between the homestay provider and the guest (tourist) creates a familiar atmosphere offered by the homestay manager as a tourism product. The use of the English language should be a policy in tourism management (Al-Saadi, 2015). The competence to communicate in English will become a key factor when meeting with foreign tourists. Foreign language brings recognition about external communication. The skill in using a foreign language is important due to better reciprocal relationships (Leslie \& Russell, 2006). English competence is required in running the homestay and that it will give benefit for informal and formal communication. Therefore, the development of communicative competence in the tourism business is very important to make tourism management successful (Al-Saadi, 2015).

\section{Methodology}

This research uses an experimental approach including quantitative research that will be made in Labuan Bajo, West Manggarai. In the first step, a researcher has an interview as a pre-study. The aim of this interview is a better understanding of the local need for developing homestay. The premier data source will be gained from the distributed questionnaire sheets. The secondary data are based on the national regulations, reports, journals, and other documents.

The Judgemental sampling technique is taken from a homestay provider in Liang Ndara village. The demography characteristics of the respondents that will be collected are concerning sex, age, recent education, and the time the homestay starts to operate. 
Gregorius Antariksa Berybe, Elisabeth Oktaviani Hanggu dan Maria Beatrix Rahinart Wellalangi

The questionnaires with the title " The awareness of the homestay provider on the importance of quality service" is shown below :

Table 1

Research questionnaires

\begin{tabular}{|c|c|c|}
\hline No & Variable & Statement \\
\hline 1 & $\begin{array}{l}\text { Tourism } \\
\text { awareness }\end{array}$ & $\begin{array}{l}\text { a. I realize that the homestay provider is a tourism } \\
\text { agent. } \\
\text { b. I understand that homestay is one of the tourism } \\
\text { products. } \\
\text { c. I know the difference between homestay and hotel. } \\
\text { d. I realize the role of the homestay provider as the } \\
\text { guide of the tourism village. } \\
\text { e. I know the existence of homestay is to support } \\
\text { tourism village development. } \\
\text { f. I have attended the training of tourism awareness for } \\
\text { homestay providers. }\end{array}$ \\
\hline 2 & $\begin{array}{l}\text { Sanitation } \\
\text { hygiene }\end{array}$ & $\begin{array}{l}\text { and a. I know the meaning of sanitation in the homestay } \\
\text { area. } \\
\text { b. I know the meaning of hygiene for the homestay } \\
\text { provider. } \\
\text { c. I understand the relationship between homestay and } \\
\text { sanitation-hygiene. } \\
\text { d. I realize that sanitation and hygiene are the } \\
\text { requirements for the homestay operational. } \\
\text { e. I have implemented the correct sanitation and hygiene } \\
\text { patterns in homestay management } \\
\text { f. I have attended training related to sanitation hygiene } \\
\text { for homestay providers. }\end{array}$ \\
\hline 3 & $\begin{array}{l}\text { Psychology } \\
\text { service }\end{array}$ & $\begin{array}{l}\text { of a. I understand that good communication creates a } \\
\text { familiar relationship with the guest. } \\
\text { b. I feel very confident when communicating with } \\
\text { guests. } \\
\text { c. I understand the ethics of communicating with local } \\
\text { and international guests. } \\
\text { d. I have a tidy performance when greeting the guest in } \\
\text { the homestay. } \\
\text { e. I often interact with the guest who spends the night at } \\
\text { the homestay. } \\
\text { f. I have attended training related to the psychology of } \\
\text { service. }\end{array}$ \\
\hline 4 & Guest service & $\begin{array}{l}\text { a. I can communicate with the guest correctly, properly, } \\
\text { and honestly. } \\
\text { b. I make a proper gesture when serving the guest. } \\
\text { c. I know the procedure of how to receive guests, the } \\
\text { information of reservations, food and drink service, } \\
\text { and the homestay facilities. } \\
\text { d. I can give a response to the guest properly and } \\
\text { honestly who complains about my homestay service. }\end{array}$ \\
\hline
\end{tabular}




\begin{tabular}{lll}
\hline & $\begin{array}{l}\text { e. I have attended training homestay guest service } \\
\text { training. }\end{array}$ \\
\hline 5 English for & a. I use English as a language when welcoming guests, \\
Communication & $\begin{array}{l}\text { reservations food and drink services, and } \\
\text { explanations of facilities and local attractions. } \\
\text { b. I often communicate with foreign tourists. } \\
\text { c. I feel confident when communicating with the } \\
\text { English language. } \\
\text { d. I feel sufficient when communicating only in the } \\
\text { Indonesian language. } \\
\text { e. I realize my English competence is increasing the } \\
\text { quality of homestay service. } \\
\text { f. I have attended an English training for the homestay } \\
\text { provider. }\end{array}$
\end{tabular}

\section{A. Data Analysis}

This research uses 4 points Likert scale with the index score ranging from " Strongly disagree" to Strongly agree" answers. The statements written in the survey are positive statements that indicate that learning is running effectively, if the respondent agrees, the index value will be even higher. Collected data will be processed using SPSS statistical program to find out the relationship between the framed questions and the variables already chosen. The index values in each category are as follows :

Table 2

4 points of Likert Scale

\begin{tabular}{ccc}
\hline Index score & Category & Code \\
\hline 1 & Strongly Disagree & SD \\
\hline 2 & Disagree & D \\
\hline 3 & Agree & A \\
\hline 4 & Strongly Agree & SA \\
\hline
\end{tabular}

\section{Results And Discussions}

\section{A. Results}

1. Demography profile

The survey was conducted on 23 homestay provider $(n=23)$ in Liang Ndara Village with the following demographic profiles :

a. Gender

Tabel 3

Gender $(\mathbf{n}=\mathbf{2 3})$

\begin{tabular}{llcccc}
\hline & Frequency & Percent & $\begin{array}{c}\text { Valid } \\
\text { Percent }\end{array}$ & $\begin{array}{c}\text { Cumulative } \\
\text { Percent }\end{array}$ \\
\hline Valid & Male & 12 & 52.2 & 52.2 & 52.2 \\
& Female & 11 & 47.8 & 47.8 & 100.0 \\
\hline
\end{tabular}


Gregorius Antariksa Berybe, Elisabeth Oktaviani Hanggu dan Maria Beatrix Rahinart Wellalangi

Tabel 3

Gender $(\mathbf{n}=\mathbf{2 3})$

\begin{tabular}{llcccc}
\hline & Frequency & Percent & $\begin{array}{c}\text { Valid } \\
\text { Percent }\end{array}$ & $\begin{array}{c}\text { Cumulative } \\
\text { Percent }\end{array}$ \\
\hline Valid & Male & 12 & 52.2 & 52.2 & 52.2 \\
& Female & 11 & 47.8 & 47.8 & 100.0 \\
& Total & 23 & 100.0 & 100.0 & \\
\hline
\end{tabular}

Table 1 shows 12 respondents or $52.2 \%$ were male and 11 respondents or $47.8 \%$ were female.

b. Age

Respondents involved in this study aged 40 years and over were 15 people followed by a range of ages 30-40 years reaching 6 people and the remaining 2 people aged between 20-30 years.

Tabel 4

Age

\begin{tabular}{llcccc}
\hline & Frequency & Percent & $\begin{array}{c}\text { Valid } \\
\text { Percent }\end{array}$ & $\begin{array}{c}\text { Cumulative } \\
\text { Percent }\end{array}$ \\
\hline Valid & 20-30 Years & 2 & 8.7 & 8.7 & 8.7 \\
& 30-40 Years & 6 & 26.1 & 26.1 & 34.8 \\
& 40-50 Years & 8 & 34.8 & 34.8 & 69.6 \\
& 50 Years up & 7 & 30.4 & 30.4 & 100.0 \\
& Total & 23 & 100.0 & 100.0 & \\
\hline
\end{tabular}

c. Last education

The highest percentage for the latest education is $60.9 \%$ or 14 people who are high school/equivalent graduates while the lowest presentation is 1 person or $4.3 \%$ respectively of bachelor and diploma graduates while the rest are junior high school graduates 5 people or $21.7 \%$ and SD graduates are 2 people $(8.7 \%)$.

\section{Tabel 5}

Last education

\begin{tabular}{llcccc}
\hline & Frequency & Percent & Valid Percent & $\begin{array}{c}\text { Cumulative } \\
\text { Percent }\end{array}$ \\
\hline Valid & SD & 2 & 8.7 & 8.7 & 8.7 \\
& SMP & 5 & 21.7 & 21.7 & 30.4 \\
& SMA/ekuivalent & 14 & 60.9 & 60.9 & 91.3 \\
& Diploma & 1 & 4.3 & 4.3 & 95.7 \\
& Sarjana & 1 & 4.3 & 4.3 & 100.0 \\
\hline
\end{tabular}


The Awareness Towards Quality of Service From Homestay Providers in Premium

Tourism Destination

Tabel 5

Last education

\begin{tabular}{llcccc}
\hline & & Frequency & Percent & Valid Percent & $\begin{array}{c}\text { Cumulative } \\
\text { Percent }\end{array}$ \\
\hline Valid & SD & 2 & 8.7 & 8.7 & 8.7 \\
& SMP & 5 & 21.7 & 21.7 & 30.4 \\
& SMA/ekuivalent & 14 & 60.9 & 60.9 & 91.3 \\
& Diploma & 1 & 4.3 & 4.3 & 95.7 \\
& Sarjana & 1 & 4.3 & 4.3 & 100.0 \\
Total & 23 & 100.0 & 100.0 & \\
\hline
\end{tabular}

d. Operational Homestay

Homestay in Liang Ndara has been operating since 2010 until now and the number continues to increase according to the head village.

Tabel 6

Operasional homestay

\begin{tabular}{cccccc}
\hline & Frequency & Percent & Valid Percent & $\begin{array}{c}\text { Cumulative } \\
\text { Percent }\end{array}$ \\
\hline Valid & 2010 & 1 & 4.3 & 4.3 & 4.3 \\
& 2013 & 6 & 26.1 & 26.1 & 30.4 \\
2014 & 4 & 17.4 & 17.4 & 47.8 \\
2015 & 1 & 4.3 & 4.3 & 52.2 \\
2016 & 2 & 8.7 & 8.7 & 60.9 \\
2017 & 2 & 8.7 & 8.7 & 69.6 \\
2018 & 6 & 26.1 & 26.1 & 95.7 \\
2019 & 1 & 4.3 & 4.3 & 100.0 \\
Total & 23 & 100.0 & 100.0 & \\
\hline
\end{tabular}

2. Tourism Awareness

Tabel 7

Tourism Awareness

\begin{tabular}{llcccc}
\hline & Frequency & Percent & $\begin{array}{c}\text { Valid } \\
\text { Percent }\end{array}$ & $\begin{array}{c}\text { Cumulative } \\
\text { Percent }\end{array}$ \\
\hline Valid & Agree & 13 & 56.5 & 56.5 & 56.5 \\
& Strongly Agree & 10 & 43.5 & 43.5 & 100.0 \\
& Total & 23 & 100.0 & 100.0 & \\
\hline
\end{tabular}

Respondents' understanding of the existence of a homestay as part of a tourism village product is very high where $100 \%$ of respondents chose to agree 
Gregorius Antariksa Berybe, Elisabeth Oktaviani Hanggu dan Maria Beatrix Rahinart Wellalangi

was 13 people or $56.5 \%$ and strongly agree was $43.5 \%$ or 10 people. It can be concluded that homestay managers have understood the role of homestays as part of tourism products. As tourism actors, homestay managers play a role in the development of tourism village products as a criterion for the host community (Budi Wahyuni \& F.P., 2020). This result is also shown by the study of (Sihombing, Gunawijaya, \& Akbar, 2017) where almost all of the respondents of the study were aware that they have an important role in participation.

3. Sanitation and Hygiene

Tabel 8

Sanitation and Hygiene

\begin{tabular}{|c|c|c|c|c|c|}
\hline & & Frequency & Percent & $\begin{array}{c}\text { Valid } \\
\text { Percent }\end{array}$ & $\begin{array}{c}\text { Cumulative } \\
\text { Percent }\end{array}$ \\
\hline \multirow[t]{4}{*}{ Valid } & $\begin{array}{l}\text { Strongly } \\
\text { Disagree }\end{array}$ & 1 & 4.3 & 4.3 & 4.3 \\
\hline & Disagree & 19 & 82.6 & 82.6 & 87.0 \\
\hline & Agree & 3 & 13.0 & 13.0 & 100.0 \\
\hline & Total & 23 & 100.0 & 100.0 & \\
\hline
\end{tabular}

The cleanliness of the homestay and the surrounding environment is one of the findings in this study. This can be seen from the respondent's data index which reached $86.9 \%$ or 20 respondents who chose "disagree and strongly disagree". This can be interpreted as a lack of understanding of the homestay provider on the importance of implementing sanitation and hygiene in the homestay environment. (Saud, Uma, \& Silwal, 2019) stated that the health, sanitation, and safety of tourists must be a priority for every homestay or hotel. Homestay providers must consider cleanliness as an important thing by doing the best possible cleaning (Budi Wahyuni \& F.P., 2020).

4. Psychology of Service

Tabel 9

Psychology of Service

\begin{tabular}{llcccc}
\hline & & Frequency & Percent & Valid Percent & $\begin{array}{c}\text { Cumulative } \\
\text { Percent }\end{array}$ \\
\hline Valid & Disagree & 8 & 34.8 & 34.8 & 34.8 \\
& Agree & 15 & 65.2 & 65.2 & 100.0 \\
& Total & 23 & 100.0 & 100.0 & \\
\hline
\end{tabular}

Respondents' understanding of behavior in interacting with guests is quite good where $65.2 \%$ or 15 respondents understand the importance of service psychology. On the other hand, the number of respondents who did not understand the importance of service psychology showed a fairly high indicator, 
namely $34.8 \%$ or 8 respondents from a total of 23 respondents. The importance of confidence and ethics when communicating with tourists is well understood by the community. It can be concluded that the homestay provider understands the importance of service psychology in the process of interacting with guests.

5. Quality of Service.

Table 10

Quality of Service

\begin{tabular}{lcccc}
\hline & Frequency & Percent & Valid Percent & $\begin{array}{c}\text { Cumulative } \\
\text { Percent }\end{array}$ \\
\hline Valid Disagree & 3 & 13.0 & 13.0 & 13.0 \\
Agree & 13 & 56.5 & 56.5 & 69.6 \\
Strongly & 7 & 30.4 & 30.4 & 100.0 \\
Agree & 23 & 100.0 & 100.0 & \\
Total & 23.0 & \\
\hline
\end{tabular}

The majority of respondents $30.4 \%$ or 7 people chose "strongly agree" and $56.5 \%$ or 13 people chose "agree". This is interpreted as Guest service procedures have been understood and implemented by the homestay provider. The results of the study (Review et al., 2013) state that quality services have a direct impact on tourist trust through tourist satisfaction. It can be concluded that the respondents have understood the importance of the quality of services provided to guests. The finding of the study from (Al-Laymoun, Alsardia, \& Albattat, 2020) shows strong and positive correlations between service quality and tourist satisfaction.

6. English for Communication

Tabel 11

English for Communication

\begin{tabular}{llcccc}
\hline & Frequency & Percent & $\begin{array}{c}\text { Valid } \\
\text { Percent }\end{array}$ & $\begin{array}{c}\text { Cumulative } \\
\text { Percent }\end{array}$ \\
\hline $\begin{array}{l}\text { Vali } \\
\text { d }\end{array}$ & $\begin{array}{l}\text { Strongly } \\
\text { Disagree }\end{array}$ & 1 & 4.3 & 4.3 & 4.3 \\
& Disagree & 17 & 73.9 & 73.9 & 78.3 \\
& Agree & 5 & 21.7 & 21.7 & 100.0 \\
Total & 23 & 100.0 & 100.0 & \\
\hline
\end{tabular}

The low ability to communicate in English with foreign tourists is found in this study. The table above shows that $73.9 \%$ or 17 people "disagree" and $4.3 \%$ or 1 person "strongly disagree" that they use English communication when interacting with foreign tourists. This is defined as the respondent's lack of English language skills when communicating with guests. English is important for information exchange in a variety of situations such as coffee shops, homestays, restaurants, and community learning centers (Nomnian, Trupp, Niyomthong, Tangcharoensathaporn, \& Charoenkongka, 2020). As a tourist actor, homestay 
providers are expected to be able to communicate in English when dealing with foreign tourists. tourism employees use English for information, followed by providing services, and offering assistance (Prachanant, 2012).

\section{B. Discussions}

The understanding of service quality is the foundation of this study. The results showed that the understanding of homestay managers related to tourism awareness, the psychology of services, and services to guests showed positive results. This means that homestay managers understand the importance of ethics and interaction in serving guests. The findings in the study (Review et al., 2013) that rural tourism (village) spots should put in place good customer relationships with tourists, execute customer relationship management and create tourist satisfaction. This is inversely proportional to the understanding of hygiene sanitation which shows negative results. This means that the level of understanding of homestay managers on the importance of sanitation is still low. The results of the study (Saud et al., 2019) show that more than $90 \%$ of homestays in Nepal had managed a healthy environment, proper sanitation, and peace and security in homestays. The status was satisfactory in the study districts. (Elysia \& Wihadanto, 2020) also state that access to basic sanitation facilities is considered as one of the aspects that should be considered to support the tourism industry, particularly in developing countries. Another negative finding from this study is the low use of English as a communication medium. This means that the English language skills of the homestay manager are still low and need to be improved. People who are required to use English at work for tourism and hospitality purposes need to improve their communicative abilities, language fluency, and accuracy (Zahedpisheh, B Abu bakar, \& Saffari, 2017).

\section{Conclusion}

As one of the tourism products in Liang Ndara village, suitable homestay management (ASEAN Homestay Standard, n.d.) must be implemented in every homestay. The application of these standards is strongly influenced by the understanding of the homestay providers about the existence of a homestay as part of a tourism product. The understanding of quality services will be the key to implementing sustainable tourism in a homestay environment

The findings of this study indicate the need for training related to the application of sanitation and hygiene principles as well as English communication skills training. This is a form of response that can be made by tourism village management to improve service quality standards from homestay managers in Liang Ndara Village, Labuan Bajo as a premium tourist destination in Indonesia. 
The Awareness Towards Quality of Service From Homestay Providers in Premium Tourism Destination

\section{REFERENCES}

Acharya, Baikuntha Prasad, \& Halpenny, Elizabeth A. (2013). Homestays as an Alternative Tourism Product for Sustainable Community Development: A Case Study of Women-Managed Tourism Product in Rural Nepal. Tourism Planning and Development, 10(4), 367-387. https://doi.org/10.1080/21568316.2013.779313. Google Scholar

Al-Laymoun, Mohammad, Alsardia, Khaled, \& Albattat, Ahmad. (2020). Service quality and tourist satisfaction at homestays. Management Science Letters, 10(1), 209-216. https://doi.org/10.5267/j.msl.2019.8.002. Google Scholar

Al-Saadi, Nawar. (2015). Importance of English Language in the Development of Tourism. Academic Journal of Accounting and Economics Researches, 4(1), 3345. Retrieved from www.worldfresearches.com. Google Scholar

Aref, Fariborz, \& Redzuan, Ma'rof. (2009). Community Leaders' Perceptions toward Tourism Impacts and Level of Building Community Capacity in Tourism Development. Journal of Sustainable Development, 2(3). https://doi.org/10.5539/jsd.v2n3p208. Google Scholar

Asian Homestay Standard. (n.d.). Google Scholar

Auliya, Anisatul, \& Aprilia, Dinda Nira. (2016). Pengaruh Hygiene Pengolahan Makanan Terhadap. 2(2). Google Scholar

Budi Wahyuni, Retno, \& F.P., Faisal. (2020). Homestay Development With Asean Homestay Standard Approach In Nglanggeran Tourism Village, Yogyakarta, Indonesia. 111(Icoborot 2018), 30-36. https://doi.org/10.2991/icoborot-18.2019.5 Google Scholar

Cárdenas, David A., Byrd, Erick T., \& Duffy, Lauren N. (2015). An exploratory study of community awareness of impacts and agreement to sustainable tourism development principles. Tourism and Hospitality Research, 15(4), 254-266. https://doi.org/10.1177/1467358415580359. Google Scholar

Elysia, Vita, \& Wihadanto, Ake. (2020). the Impact of Poor Sanitation on Tourism Development: a Global Review. Indonesian Journal of Urban and Environmental Technology, 3(2), 220. https://doi.org/10.25105/urbanenvirotech.v3i2.6720. Google Scholar

Ismail, Mohd Noor Ismawi, Hanafiah, Mohd Hafiz, Aminuddin, Norliza, \& Mustafa, Norazah. (2016). Community-based Homestay Service Quality, Visitor Satisfaction, and Behavioral Intention. Procedia - Social and Behavioral Sciences, 222, 398-405. https://doi.org/10.1016/j.sbspro.2016.05.192. Google Scholar.

Kontogeorgopoulos, Nick, Churyen, Anuwat, \& Duangsaeng, Varaphorn. (2015). Homestay Tourism and the Commercialization of the Rural Home in Thailand. 
Gregorius Antariksa Berybe, Elisabeth Oktaviani Hanggu dan Maria Beatrix Rahinart Wellalangi

Asia Pacific Journal of Tourism Research, 20(1), 29-50. https://doi.org/10.1080/10941665.2013.852119. Google Scholar

Leslie, David, \& Russell, Hilary. (2006). The importance of foreign language skills in the tourism sector: A comparative study of student perceptions in the UK and continental Europe. Tourism Management, 27(6), 1397-1407. https://doi.org/10.1016/j.tourman.2005.12.016. Google Scholar

Nomnian, Singhanat, Trupp, Alexander, Niyomthong, Wilawan, Tangcharoensathaporn, Prakaimook, \& Charoenkongka, Anan. (2020). Language and community-based tourism: Use, needs, dependency, and limitations. Austrian Journal of South-East Asian Studies, 13(1), 57-79. https://doi.org/10.14764/10.ASEAS-0029. Google Scholar

Prachanant, Nawamin. (2012). Needs Analysis on English Language Use in Tourism Industry. Procedia - Social and Behavioral Sciences, 66, 117-125. https://doi.org/10.1016/j.sbspro.2012.11.253. Google Scholar

Review, Management Quarterly, Osman, Zahir, \& Sentosa, Ilham. (2013). Influence of Customer Satisfaction on Service Quality and Trust. 4(2), 12-25. Google Scholar

Saud, Tul Bahadur, Uma, Prof, \& Silwal, Kant. (2019). Health, Sanitation, and Security in Homestay of Nepal. 5(11), 14-16. Google Scholar

Sihombing, Ir Antony, Gunawijaya, Jajang, \& Akbar, Poeti Nazura Gulfira. (2017). Local tourism awareness and knowledge: Community views in Wanayasa. EReview of Tourism Research, 14(5-6), 188-213. Google Scholar

Suhartoyo, Suhartoyo. (2019). Implementasi Fungsi Pelayanan Publik dalam Pelayanan Terpadu Satu Pintu (PTSP). Administrative Law and Governance Journal, 2(1), 143-154. https://doi.org/10.14710/alj.v2i1.143-154. Google Scholar

Wahyunanto. (2018). Penerapan Hygiene Dan Sanitasi Dalam Upaya Peningkatan Mutu Kualitas Food And Baverage (Studi Pada Pantai Konang Desa Ngelebeng Kecamatan Panggul Kabupaten Trenggalek). Jurnal Administrasi Bisnis, 58(2), 146-154. Google Scholar

Wedatama, Abid Affandi, \& Mardiansjah, Fadjar Hari. (2018). Pengembangan Homestay Berbasis Masyarakat Pada Kampung Homestay Borobudur. Jurnal Pengembangan Kota, 6(2), 135. https://doi.org/10.14710/jpk.6.2.135-143. Google Scholar

Zahedpisheh, Nahid, B Abu bakar, Zulqarnain, \& Saffari, Narges. (2017). English for Tourism and Hospitality Purposes (ETP). English Language Teaching, 10(9), 86. https://doi.org/10.5539/elt.v10n9p86. Google Scholar 
The Awareness Towards Quality of Service From Homestay Providers in Premium Tourism Destination

\section{Copyright holder:}

Gregorius Antariksa Berybe, Elisabeth Oktaviani Hanggu dan Maria Beatrix Rahinart Wellalangi (2021)

\section{First publication right:}

Journal Syntax Literate

This article is licensed under:

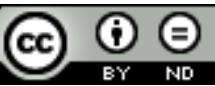

